\title{
First results on Microcystis ichthyoblabe Kütz. toxic bloom in the hypertrophic Oued Mellah reservoir (Morocco)
}

\author{
B. Sabour ${ }^{1,2}$ \\ M. Loudiki ${ }^{*}$ \\ B. Oudra ${ }^{2}$ \\ S. Oubraim ${ }^{3}$ \\ B. Fawzi ${ }^{3}$ \\ S. Fadlaoui ${ }^{3}$ \\ M. Chlaida ${ }^{3}$ \\ V. Vasconcelos ${ }^{4}$
}

Keywords : blooms, Microcystis ichthyoblabe, microcystins, HPLC-PDA, ELISA, Morocco.

The Oued Mellah reservoir $\left(33^{\circ} 30^{\prime} \mathrm{N}-07^{\circ} 20^{\prime} \mathrm{W}\right)$ is a shallow brackish lake located $25 \mathrm{~km}$ North of Casablanca. A study of the phytoplankton community. of this lake shows that it is affected by potentially toxic blooms of Cyanobacteria and Haptophyceae. Microcystis ichthyoblabe (first time recorded from Morocco), Anabaena aphanizomenoides, Oscillatoria chlori$n a$ (Cyanobacteria) and Prymnesium parvum (Haptophyceae) constitute the dominant phytoplankton taxa. M. ichthyoblabe starts its growth in late spring. In 1999, it formed a spectacular bloom during May-June, invading the lake with a maximal biomass of $298 \mathrm{mg}_{\mathrm{FW}} \cdot \mathrm{L}^{-1}$. This proliferation coincided with high temperatures, strong luminous intensity, alkaline $\mathrm{pH}$ and low to undetectable contents of nitrates and orthophosphates. The toxicity of the $M$. ichthyoblabe bloom material was first determined by mouse bioassay. Bloom material collected during the maximal development phase has an $\mathrm{LD}_{50}$ about $502 \mathrm{mg}_{\mathrm{DW}} \cdot \mathrm{Kg}^{-1}$. Hepatotoxicity was confirmed by histopathological study. The total contents of microcystins determined by ELISA technique both for bloom material and the isolated strain are about 0.79 and $5.4 \mu \mathrm{g} \cdot \mathrm{gDW}^{-1}$ respectively. Analysis by HPLC-PDA allows the detection of 11 variants of microcystins. The use of the microcystin-LR authentic sample showed the absence of this microcystin variant in the samples analysed.

Premières données sur un bloom toxique à Microcystis ichthyoblabe Kütz. dans le lac-réservoir hypereutrophe Oued Mellah (Maroc)

Mots-clés : blooms, Microcystis ichthyoblabe, microcystines, HPLC-PDA, ELISA, Maroc.

Le lac de barrage Oued Mellah $\left(33^{\circ} 30^{\prime} \mathrm{N}-07^{\circ} 20^{\prime} \mathrm{W}\right)$ est un réservoir saumâtre peu profond situé à $25 \mathrm{Km}$ au nord de Casablanca. L'étude du peuplement phytoplanctonique montre qu'il est le siège de développement de blooms variés de Cyanobactéries et d'Haptophycées potentiellement toxiques. Microcystis ichthyoblabe, signalée pour la première fois au Maroc, Anabaena aphanizomenoides, Oscillatoria chlorina et Prymnesium parvum sont les espèces dominantes. Selon les années, $M$.

\footnotetext{
1. Faculté des Sciences et Techniques Mohammadia, Département de Biologie, Mohammadia, Maroc. E-mail : sabour.brahim@lycos.com

2. Faculté des Sciences Semlalia, Département de Biologie, Laboratoire d'Algologie, B.P. 2390, 40000 Marrakech, Maroc.

3. Faculté des Sciences Ben M'sik, B.P. 7955 Sidi Othmane, Département de Biologie, Laboratoire d'Ecologie et d'Environnement, Casablanca, Maroc.

4. Faculdade de Ciências do Porto, Departamento de Zoologia e Antropologia, Lab. Ecotoxicologia, 4050 Porto and CECA-ICETA, Campus Agràrio de Vairão, 4480 Vila do Conde, Portugal.

* Correspondent author : E-mail : loudiki@ucam.ac.ma
} 
ichthyoblabe prolifère dès le printemps. En mai-juin 1999, cette espèce a formé un bloom spectaculaire envahissant le lac avec une biomasse maximale de $298 \mathrm{mg} / \mathrm{PF} . \mathrm{L}^{-1}$. Cette prolifération a coïncidé avec des températures relativement élevées, une forte intensité lumineuse, des $\mathrm{pH}$ alcalins et des teneurs faibles voir nulles en nitrates et orthophosphates. La toxicité de $M$. ichthyoblabe a été évaluée par le biotest souris. La $\mathrm{DL}_{50}$ calculée pour un échantillon du bloom en phase de développement maximal est de $502 \mathrm{mg} . \mathrm{Kg}^{-1}$. L'hépatotoxicité a été confirmée par une étude histopathologique. Les teneurs en microcystines totales, déterminées dans le bloom et la souche isolée de $M$. ichthyoblabe par la technique ELISA, sont faibles et respectivement de l'ordre de 0,79 et $5,4 \mu \mathrm{g} \cdot \mathrm{g}^{-1}$. L'analyse par chromatographie liquide à haute performance avec détecteur à barrette de diodes (HPLC-PDA) montre la présence de 11 variantes de microcystines avec absence de la microcystine-LR en comparaison avec le chromatogramme du standard.

\section{Introduction}

Blue-green algal blooms are a diagnostic of accelerating eutrophication and are becoming an increasing problem in fresh, brackish and marine waters (Paerl 1996, Falconer 1998). These phenomena have been reported in many countries throughout the world (Skulberg et al. 1984, Carmichael \& Falconer 1993) and have been known to cause death in livestock and wildlife besides cases of human illness and mortality (e.g. Jochimsen et al. 1998, Kuiper-Goodman et al. 1999). Cyanobacterial toxins include hepatotoxic peptides, cytotoxic alkaloid, neurotoxic and lipopolysaccharides (Falconer 1999). Microcystis is the most cosmopolitan of the cyanobacterial genera (Carmichael 1996) and its blooms and scums are often extensively persistent and, in certain latitudes, are dominant thorough the year (Zohary \& Robarts 1990). This genus includes a wide range of toxic species such as $M$. aeruginosa Kütz, $M$. wesenbergii Kom., $M$. flos aquae Elenkin, $M$. viridis Lemm. and M. ichthyoblabe Kütz. (Carmichael \& Falconer 1993, Watanabe 1996, Falconer 1998). The later species sometimes forms heavy water blooms in mesotrophic and eutrophic waters, but not in polluted water bodies. It commonly occurs in the northern areas of the temperate zone (Komarek 1991). In Morocco, M. ichthyoblabe blooms was never recorded before (Loudiki et al., submitted). This paper presents the first results on the dynamics of phytoplankton in the Oued Mellah lake-reservoir, particularly of $M$. ichthyoblabe, the cyanobacterium responsible for spectacular blooms. In addition, data on its toxicity using mouse bioassay, detection and quantification of microcystins by High Performance Liquid Chromatography with Photodiode Array Detection (HPLC-PDA) and Enzyme-Linked ImmunoSorbent Assay (ELISA) techniques are presented and discussed.

\section{Material and methods}

\subsection{Study area and water sampling}

Geographic situation and general characteristics of Oued Mellah lake are presented in the figure 1 and table 1 . The sampling was carried out at monthly intervals in 1999 and weekly during the bloom periods. Water samples were collected in the station at the deepest part $(7-9 \mathrm{~m})$ of the reservoir at $0,1,2,4 \mathrm{~m}$ of depth and near the bottom with a Van Dorn water

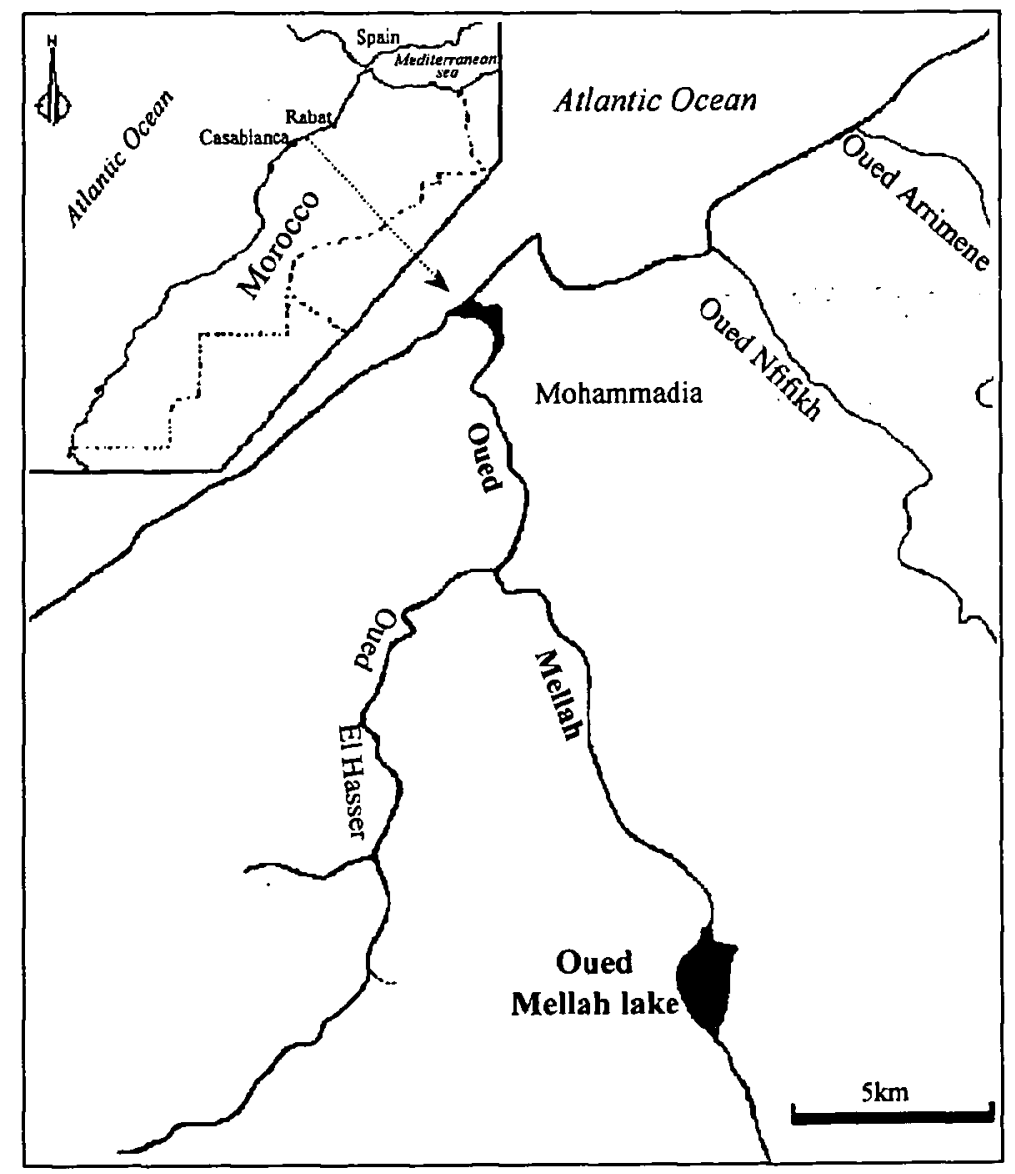

Fig. 1. Geographic situation of Oued Mellah reservoir.

Fig. 1. Situation géographique du lac-réservoir Oued Mellah. 
Table 1. General characteristics of Oued Mellah reservoir.

Tableau 1. Caractéristiques générales du lac-réservoir Oued Mellah.

Oued Mellah reservoir

\begin{tabular}{|c|c|}
\hline Date of construction & $1928-1931$ \\
\hline Geographical situation & $33^{\circ} 30^{\prime} \mathrm{N}-07^{\circ} 20^{\prime} \mathrm{W}$ \\
\hline River & Oued Mellah \\
\hline Depth max & $9 \mathrm{~m}$ \\
\hline Depth average & $4 \mathrm{~m}$ \\
\hline Normal elevation & $101,75 \mathrm{NGM}$ \\
\hline Total capacity & $18 \mathrm{Mm}^{3}$ \\
\hline Useful capacity & $8,8 \mathrm{Mm}^{3}$ \\
\hline Surface & 250 ha \\
\hline Catchment surface & $1800 \mathrm{~km}^{2}$ \\
\hline Catchment geology & $\begin{array}{l}\text { Primary schist surmounted by greso-maghrebian tile with triasic } \\
\text { saliferous clays and altered basalts }\end{array}$ \\
\hline Bioclimat & Semi-arid thermomediterranean with hot winter \\
\hline$\ddot{\mathrm{U}} \mathrm{se}$ & $\begin{array}{l}\text { Domestic water production, irrigation, pisciculture, electricity, } \\
\text { sport fishing and recreation }\end{array}$ \\
\hline Ecological interest & National Biologic and Ecological Interest Site (B.E.I.S. $n^{\circ} \mathrm{H} 8$ ) \\
\hline
\end{tabular}

sămplèr.-Temperature, $\mathrm{pH}$ (pH-meter WTW 90), Transparency (Secchi disk), conductivity (WTW LF90) and incident light (lux-meter LX-101) were measured in situ. The other physical and chemical parameters were determined within 24 hours at the laboratory according to the standard methods (Rodier 1984, AFNOR 1994).

\subsection{Phytoplankton analysis}

For qualitative studies, phytoplankton samples were collected with $40 \mu \mathrm{m}$ mesh size net and observed with a light microscope for identification. Quantitative samples of 0.5 litre of water were immediately fixed in the field with a neutralised formaldehyde solution. Phytoplankton was counted using sedimentation chambers and an inverted microscope using Utermöhl's technique (1958). The Microcystis cells were counted with haematocytometer (Mallassez) after disintegration of colonies by ultrasonication. The biomass was estimated in fresh weight $\left(\mathrm{mg}_{\mathrm{FW}} \cdot \mathrm{L}^{-1}\right)$ from the biovolume of the taxa ; these were calculated by considering the cells as solid geometric shapes (Wetzel \& Likens 1991) and assuming that the organisms density was $1 \mathrm{~g} . \mathrm{cm}^{-3}$.

\subsection{Toxicity confirmation and microcystins analy- sis}

Natural blooms of $M$. ichthyoblabe was collected by concentrating cyanobacteria during maximal growth of bloom (30/05/1999) with a $40 \mu \mathrm{m}$ mesh size plankton net. M. ichthyoblabe strains were isolated and cultivated in Z8 medium (Hughes et al. 1958, modified by Kotai 1972). Concentrated algal samples of both bloom and strains were lyophilised and stored at $-40^{\circ} \mathrm{C}$.

The toxicity was measured by intraperitoneal (i.p.) mouse bioassay using 20-30 g male Swiss mice. Sus- 
pensions of lyophilised cells in $0.9 \% \mathrm{NaCl}$ solution were injected in pairs of mice per dose level. Symptoms were registered and dead animals were observed internally for signs of hepatotoxicity. The toxicity was quantified as $\mathrm{LD}_{50}$ (Lethal Dose for $50 \%$ mortality of tested animals). For confirmation of poisoning signs, liver histopathological examination was performed.

\subsection{Immunological detection of microcystins}

For toxins quantification, an enzyme-linked immunosorbent assay (ELISA) was performed and polyclonal antibodies microplate Enviro Gard ${ }^{\circledR}$ Microcystins Kit were used.

\subsection{High Performance Liquid Chromatography - Photodiode Array Detection (HPLC-PDA)}

For the toxins analysis for both Microcystis natural bloom and isolated strain, an extraction was required prior to HPLC separation. Toxins were extracted three times with $100 \%$ methanol (Lawton et al. 1994) from lyophilised cells after sonication using an ultrasonic desintegrator (Vibra cell ${ }^{\mathrm{TM}}$, Sonics \& materials inc.). Extracts were centrifuged $\left(10 \mathrm{~min}, 4^{\circ} \mathrm{C}, 5000 \mathrm{xg}\right)$ and supernatants were diluted with ultrapure water (MilliQplus) down to $20 \%$ methanol. The extracts were loaded in a Bond Elut C18 cartridge (Sep-Pak® Vac C18 $6 \mathrm{cc}$, Waters Corporation, Milford USA) previously activated with methanol and water. After washing the column with $20 \%$ methanol and water, the toxic fractions were eluted with $100 \%$ methanol. The fractions were evaporated completely at $40^{\circ} \mathrm{C}$ (with an evaporator MEYER N-EVAP, USA). Prior to HPLC analysis, the residues were resolved in $50 \%$ methanol and filtered through a $0.2 \mu \mathrm{m}$ filter. The detection of microcystins was performed with an HPLC system composed of a pump L-7100, a L-7200 autosampler and a L-7450 photodiode array detector (LaChrom Merck HITACHI). Extracts were separated on LiChrospher R 100, $5 \mu \mathrm{m}$ ODS, (LiChroCART® 250-4 cartridge system, Merck, KGaA, Germany) using a gradient of aqueous acetonitrile (with $0.05 \%$ TFA) according to the method of Lawton et al. (1994) with a flow of 1 ml.min ${ }^{-1}$. UV spectra were obtained from 220 to 400 nm.

\section{Results and discussion}

\subsection{General characteristics of the phytoplankton}

The qualitative analysis of the phytoplankton community shows that 69 taxa were inventoried. The spe- cies Prymnesium parvum N. Carter (Sabour et al. 2000) and Microcystis ichthyoblabe Kütz. 1843 were inventoried for the first time in Moroccan water bodies. The occurrence of these species does not imply their new apparition in Morocco but rather the lack of previous phytoplankton studies in Oued Mellah lake. Chlorophyceae represented $37 . \%$ of the total specific relative abundance, followed by Cyanobacteria (26\%) (Table 2) and Bacillariophyceae (19\%). In spite of the numerous inventoried taxa, the phytoplanktonic seasonality showed that only some species $(M$. ichthyoblabe, Anabaena aphanizomenoides forti and $P$. parvum) are quantitatively important.

The chlorophyll a variation shows that the maximal values 222 and $322 \mu \mathrm{g} . \mathrm{L}^{-1}$ were respectively recorded in May and September 1999 (Fig. 2a). These values coincided with a maximal development of two algal blooms constituted by Microcystis (Mai-June) and Anabaena associated with Prymnesium (August-September). The annual average of chlorophyll $\mathrm{a}$ is also elevated ( $75.63 \mu \mathrm{g} . \mathrm{L}^{-1}$ ) which allows to classify the Oued Mellah lake in the hypertrophic category.

The phytoplanktonic biomass, expressed in fresh weight, showed a great temporal variation (Fig. 2b). This biomass was very weak in winter $\left(2.9 \mathrm{mg}_{\mathrm{FW}} \cdot \mathrm{L}^{-1}\right)$ with dominance of Chlorophyceae (72\%) and Chrysophyceae (22\%) (Fig. 3). The spring was marked by the predominance of Cyanobacteria $(97 \%)$, represented essentially by $M$. ichthyoblabe, forming a spectacular bloom during the May-June period. Phytoplanktonic biomass of $300 \mathrm{mg}_{\mathrm{FW}} . \mathrm{L}^{-1}$, mainly bound to the development of $M$. ichthyoblabe bloom, constituted the maximal value. In summer, the Cyanobacteria represented again $76.9 \%$ of the total biomass, with a second bloom of A. aphanizomenoides. This season was also marked by the beginning development of Chrysophyceae $(17 \%)$ represented only by $P$. parvum. In autumn, the weak recorded biomass $\left(7 \mathrm{mg}_{\mathrm{FW}} \cdot \mathrm{L}^{-1}\right)$ was constituted essentially by Chrysophyceae (73\%) and Cyanobacteria $(21 \%)$.

\subsection{Kinetic growth of Microcystis ichthyoblabe bloom}

Isolated strains and bloom-forming Microcystis were identified as $M$. ichthyoblabe (Starmach 1966, Komarek \& Anagnostidis 1986, Watanabe 1996, HuberPestalozzi 1938). This species is characterized by groups of gathered small cells (average $3 \mu \mathrm{m}$ in diameter) disposed in fine, colourless and diffluent mucilage. The distribution of cells in colonies is irregular, groups of cells are sometimes localised in a mass of scarcely distributed cells (Komarek 1991). 
Table 2. Inventory of planktonic cyanobacteria in Oued Mellah reservoir.

Tableau 2. Cyanobactéries planctoniques inventoriées dans le lac-réservoir Oued Mellah.

\section{Bloom forming-species \\ Microcystis ichthyoblabe Kützing \\ Anabaena aphanizomenoides Forti}

Other inventoried cyanobacteria

Microcystis pulverea f. delicatissima Elenkin

Synechocystis salina Wislouch

Synechococcus elongatus Nägeli

Merismopedia sp.

Phormidium ambiguum Gomont

Phormidium treleasi Gomont

Lyngbya aestuarii Liebmann

Oscillatoria brevis Gomont

Oscillatoria chlorina Kützing
Oscillatoria gracilis Böcher

Oscillatoria lauterbornii Schmidle

Oscillatoria limnetica Lemmermann

Planktothrix agardhii (Gom.) Anagnostidis \&

Komarek [basionym : Oscillatoria agardhii

Gom.]

Spirulina major Kützing

Anabaena spiroides Klebahn
Conversely to $M$. aeruginosa Kütz. which is the most common species of the genus, data on the geographic distribution, ecology and toxicity of $M$. ichthyoblabe are scarcely reported. For Moroccan waters, we have inventoried this species for the first time in June 1997 in the Oued Mellah lake. It was noted in Europe by Huber-Pestallozi (1938) in the Baltic sea, in Greece by Gkelis et al. (2000), in Czechoslovakia by Kopp \& Hetesa (2000) and quoted by Tilden (1909) in some American lakes. In Japanese lakes, Komarek (1991) reported 26 citations of this species.

The weekly follow-up of the growth (Fig. 4) shows that $M$. ichthyoblabe started its development since the beginning of May. This species presented an exponential growth phase that progresses until the end of May, where the high biomass $\left(298 \mathrm{mg}_{\mathrm{FW}} \cdot \mathrm{L}^{-1}\right)$ constituted the first annual peak and represented $99 \%$ of the total phytoplankton biomass. During this phase (05 - 30 May), the net maximal growth rate $\left(\mu_{\max }\right)$ was 0.23 day $^{-1}$. This phase is immediately followed by a fast declining phase (30 May-18 July). Beyond this decline, $M$. ichthyoblabe persists with a low biomass varying between 5.6 and $20.7 \mathrm{mg}_{\mathrm{FW}} \cdot \mathrm{L}^{-1}$, and disappears from the water column at the end of August. The profiles of vertical distribution (Fig. 5) show that $M$. ichthyoblabe especially colonizes surface water layers with very high densities. This distribution is the main cause of the extended blooms (see photo1) that can cover about 50 to $75 \%$ of the total surface of the lake.

The follow-up of environmental parameters (Table 3 ) during the $M$. ichthyoblabe bloom show that this period was characterized by relatively high water temperatures $\left(25 \pm 1^{\circ} \mathrm{C}\right)$, strong luminous intensity $(1605$ $\left.\pm 335 \mu \mathrm{mol} \cdot \mathrm{m}^{-2} . \mathrm{s}^{-1}\right)$, high turbidity $\left(\mathrm{Z}_{\mathrm{s}}=0.7 \pm 0.1 \mathrm{~m}\right)$, alkalin $\mathrm{pH}(8.26 \pm 0.1)$ and high salinity $(8.6 \pm 2 \%$ ) Contents in major nutrients, specially nitrogen and phosphorus, are very limiting. Indeed, during the $\mathrm{Mi}$ crocystis bloom, soluble reactive phosphorus $\left(\mathrm{P}-\mathrm{PO}_{4}\right)$ was below the limit of detection, while nitrate concentrations were very low $\left(0.08 \pm 0.11 \mathrm{mgN}-\mathrm{NO}_{3} \cdot \mathrm{L}^{-1}\right)$. The yearly minimal value of the TN/TP atomic ratio (68) coincided with the maximal development of $M$. ichthyoblabe. However, this value remained very high when compared to 20 , considered as the maximum limit for the development of cyanobacterial blooms (Paerl 1996). Besides, Smith (1983) reported that cya- 

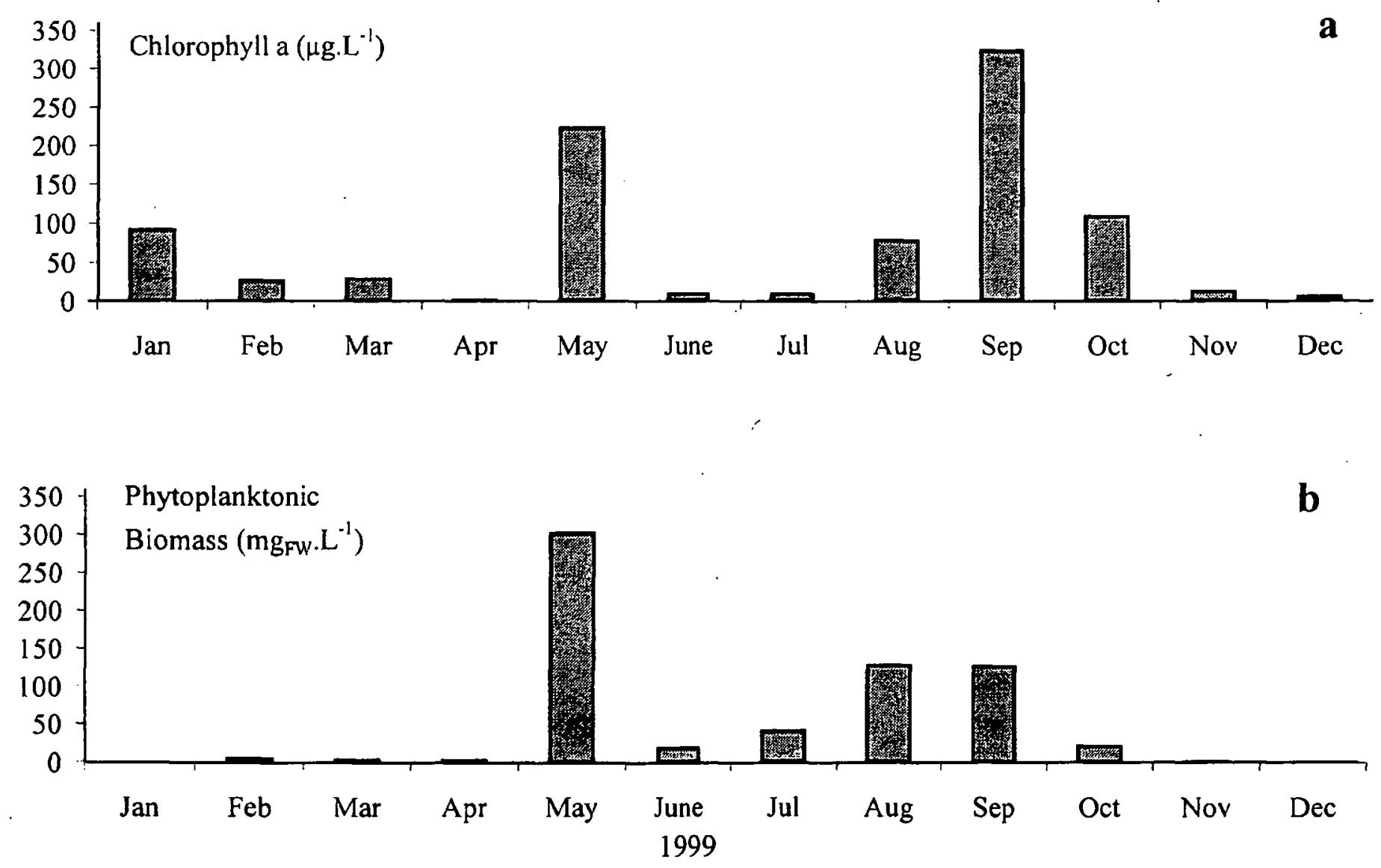

Fig. 2. Temporal variation of chlorophyll a (a) and total phytoplanktonic biomass (b) in the surface of waters during 1999. Fig. 2. Evolution de la chlorophylle a (a) et de la biomasse phytoplanctonique totale (b) dans les eaux de surface en 1999.

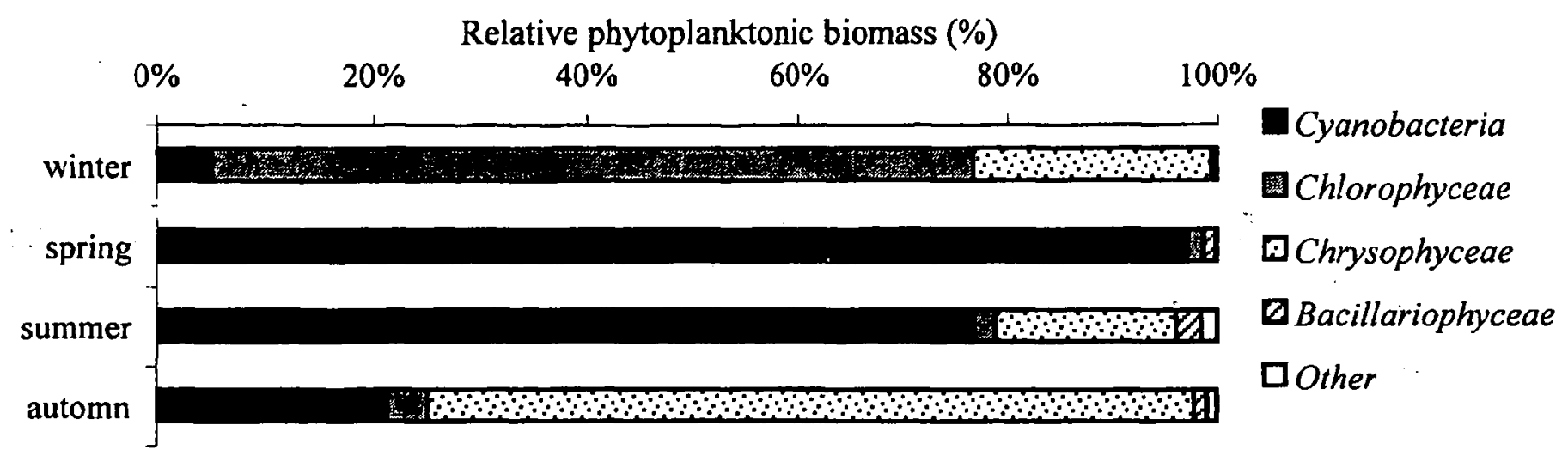

Fig. 3. Seasonal evolution of principal phytoplanktonic classes in the surface of waters during 1999.

Fig. 3. Evolution saisonnière des principaux groupes phytoplanctoniques dans les eaux de surface en 1999.

nobacteria tended to be rare when the atomic ratio TN/TP exceeded 60, from a survey of 17 world-wide lakes. These abiotic conditions are comparable with those quoted for Microcystis aeruginosa blooms in Lalla Takerkoust (Sbiyyaa 1997) and El Kansera Moroccan reservoir-lakes (Derraz 1995). The ecological success of $M$. ichthyoblabe, under limiting conditions, depends probably on these ecophysiological properties close to those of many blue-green algae : buoyancy regulation, nutrient storage, phycosphere-microbial associations, high resistance to grazing (Healey 1982, Pettersson et al. 1993, Paerl \& Tucker 1995, Paerl 1996).

\subsection{Microcystis ichthyoblabe bloom toxicity}

The toxicity of $M$. ichthyoblabe bloom has been demonstrated by i.p. mouse bioassay. Lyophilised cells sampled in maximal development phase (30/05/1999) give an i.p. $\mathrm{LD}_{50}$ of $502 \mathrm{mg}_{\mathrm{DW}} \cdot \mathrm{kg}^{-1}$. body weight. The autopsy of intoxicated mice reveals that the most affected organ was liver which becomes enlarged and inflated with blood and darker. The mice administrated doses have a low increase in liver weight up to $7.3 \%$ of the total body weight (the control was about $5 \%$ ). These symptoms are comparable to those induced by cyanobacterial hepatotoxins. 


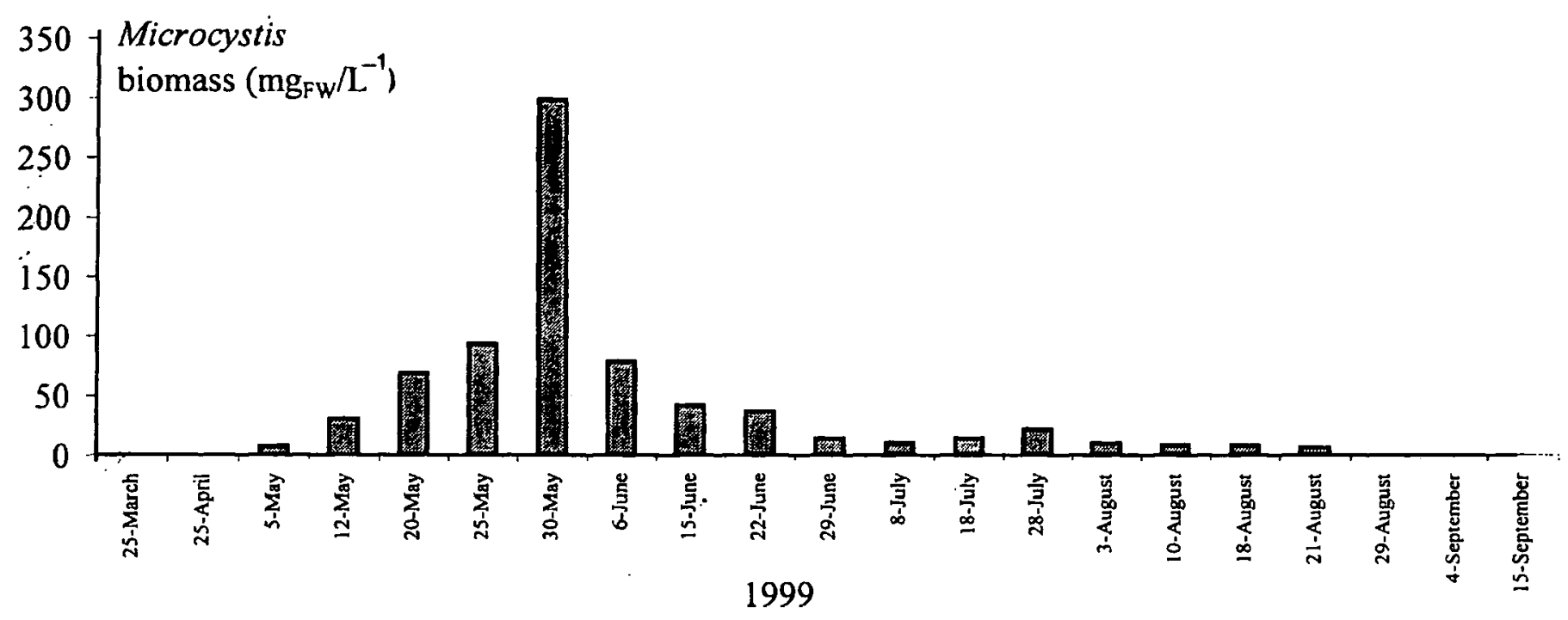

Fig. 4. Growth kinetic of Microcystis ichthyoblabe in the surface waters during 1999.

Fig. 4. Cinétique de croissance de Microcystis ichthyoblabe dans les eaux de surface en 1999.

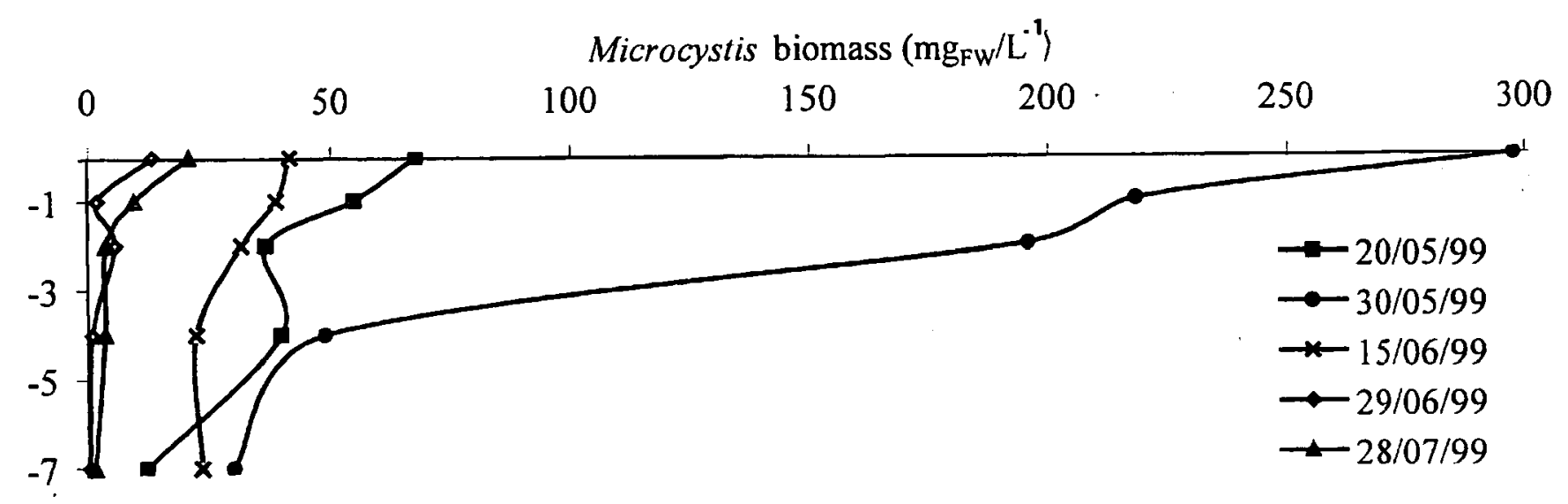

Fig. 5. Vertical distribution of Microcystis ichthyoblabe in Oued Mellah reservoir.

Fig. 5. Distribution verticale de Microcystis ichthyoblabe dans les eaux du lac-réservoir Oued Mellah.

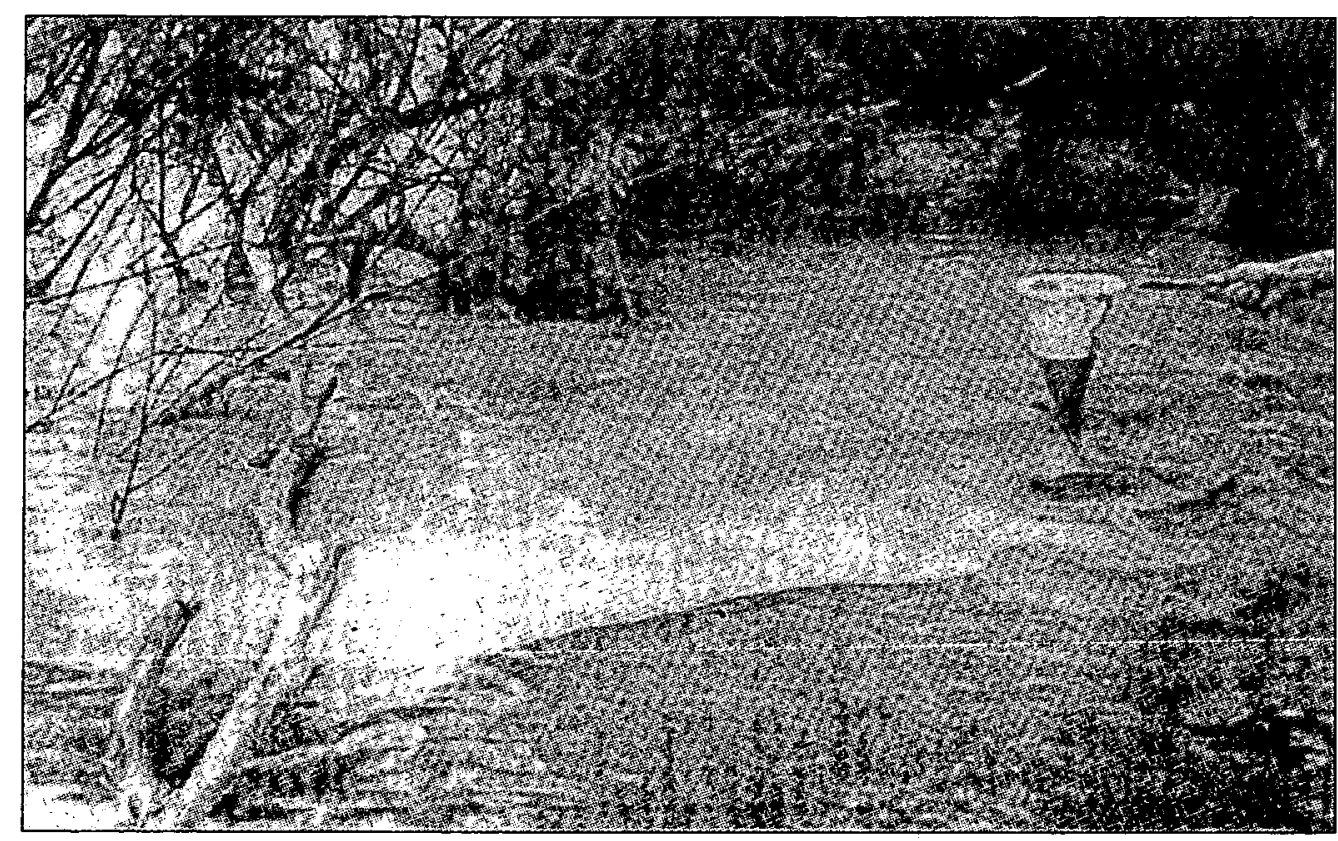

Photo1. Microcystis ichthyoblabe bloom in Oued Mellah reservoir (June 1999).

Photo 1. Bloom à Microcystis ichthyoblabe dans le lac-réservoir Oued Mellah (Juin 1999). 
Table 3. Some physical and chemical parameters measured in surface waters during and in $M$. ichthyoblabe bloom and no bloom periods in 1999.

Tableau 3. Quelques paramètres physico-chimiques mesurés dans les eaux de surface durant et en dehors de la période du bloom à $M$. ichthyoblabe en 1999.

\begin{tabular}{lcccc}
\hline & \multicolumn{2}{c}{ Bloom period (May-June) } & \multicolumn{2}{c}{ Out of bloom } \\
\hline Parameters & min-max & average & min-max & average \\
\hline Water temperature $\left({ }^{\circ} \mathrm{C}\right)$ & $24-28$ & $25.6 \pm 1.23$ & $12-28$ & $19.6 \pm 5.9$ \\
Incident luminosity & $1368-1842$ & $1605 \pm 335$ & $509-1912$ & $1266 \pm 481$ \\
$\left(\mu\right.$ mol.m $\left.{ }^{-2} . \mathrm{s}^{-1}\right)$ & & & & \\
Secchi disk $(\mathrm{m})$ & $0.6-0.77$ & $0.7 \pm 0.1$ & $0.35-0.76$ & $0.53 \pm 0.16$ \\
pH & $8.10-8.38$ & $8.26 \pm 0.08$ & $7.67-9.04$ & $8.25 \pm 0.42$ \\
Conductivity $\left(\mathrm{ms} . \mathrm{cm}^{-1}\right)$ & $3.66-4.25$ & $3.99 \pm 0.24$ & $2.84-4.93$ & $3.94 \pm 0.8$ \\
Salinity $(\%)$ & $7.2-10.1$ & $8.64 \pm 2.04$ & $6.37-12.64$ & $9.35 \pm 2.96$ \\
SRP $\left(\mu \mathrm{gP}-\mathrm{PO} 4 . \mathrm{L}^{-1}\right)$ & 0 & 0 & $0-5.22$ & $0.52 \pm 1.65$ \\
Nitrates $\left(\mu \mathrm{gN}-\mathrm{NO} 3 . \mathrm{L}^{-1}\right)$ & $0-155$ & $77.5 \pm 109.6$ & $66.69-2510$ & $854.88 \pm 937.5$ \\
Atomic TN/TP & $68.58-195.35$ & $131.96 \pm 89.64$ & $92.55-421.17$ & $229.51 \pm 128.35$
\end{tabular}

In comparison with $M$. aeruginosa bloom of Lalla Takerkoust lake which exhibits a higher toxicity (Sbiyyaa 1997, Oudra et al. 2001), M. ichthyoblabe bloom appears to be 6 to 250 times less toxic and could be considered as slightly toxic $\left(\mathrm{LD}_{50}\right.$ between 500 and $1000 \mathrm{mg}_{\mathrm{DW}} / \mathrm{kg}$ ) according to Lawton et al. (1994) classification.

\subsection{ELISA and HPLC analysis of microcystins}

The results of microcystin quantification by ELISA in $M$. ichthyoblabe natural bloom and laboratory isolated strain showed that the total microcystin contents are respectively equal to $0.79 \pm 0.25$ and $5.4 \pm 0.45$ $\mu \mathrm{g} . \mathrm{g}_{\mathrm{DW}}{ }^{-1}$. The latest values are very low in comparison with the total microcystin contents of 130-650 $\mu \mathrm{g} . \mathrm{gDw}^{-1}$ in $M$. aeruginosa isolated strains and 710$8800 \mu \mathrm{g} \cdot \mathrm{g}_{\mathrm{DW}}{ }^{-1}$ in natural blooms in Lalla Takerkoust lake determined by Oudra (2001). These results explain the low toxicity evaluated by mouse bioassay and agree with the results of Watanabe et al. (1996) which reported that $M$. ichthyoblabe includes both toxic and non-toxic strains.
The presence of microcystins in extracts of both natural bloom and laboratory culture of $\mathrm{M}$. ichthyoblabe was confirmed by HPLC-PDA. The HPLC chromatograms (Figs. 6a, 6b) presented the similar peaks with very low absorbances in the case of isolated strain with :

- Absence of the microcystin-LR in comparison with the standard chromatogram (Fig. 6c);

- Presence of 11 peaks corresponding to unidentified microcystins with typical UV spectra. All fractions have higher retention times (RT). This means that these microcystins are more lypophylic (RT between 24.72 and $30.95 \mathrm{~min}$ ) than LR (RT : $16.24 \mathrm{~min}$ ), such are LA, LY, LW or LF (Lawton et al. 1994).

The Cyanobacteria blooms in Oued Mellah lake-reservoir as a symptom of increased eutrophication is not only an aesthetic problem, as it reduces recreation, but also an ecological and sanitary problem because of the toxins production by $M$. ichthyoblabe bloom-forming species. In this context, thorough investigations on ecology, physiology, toxicity and toxinology of this 

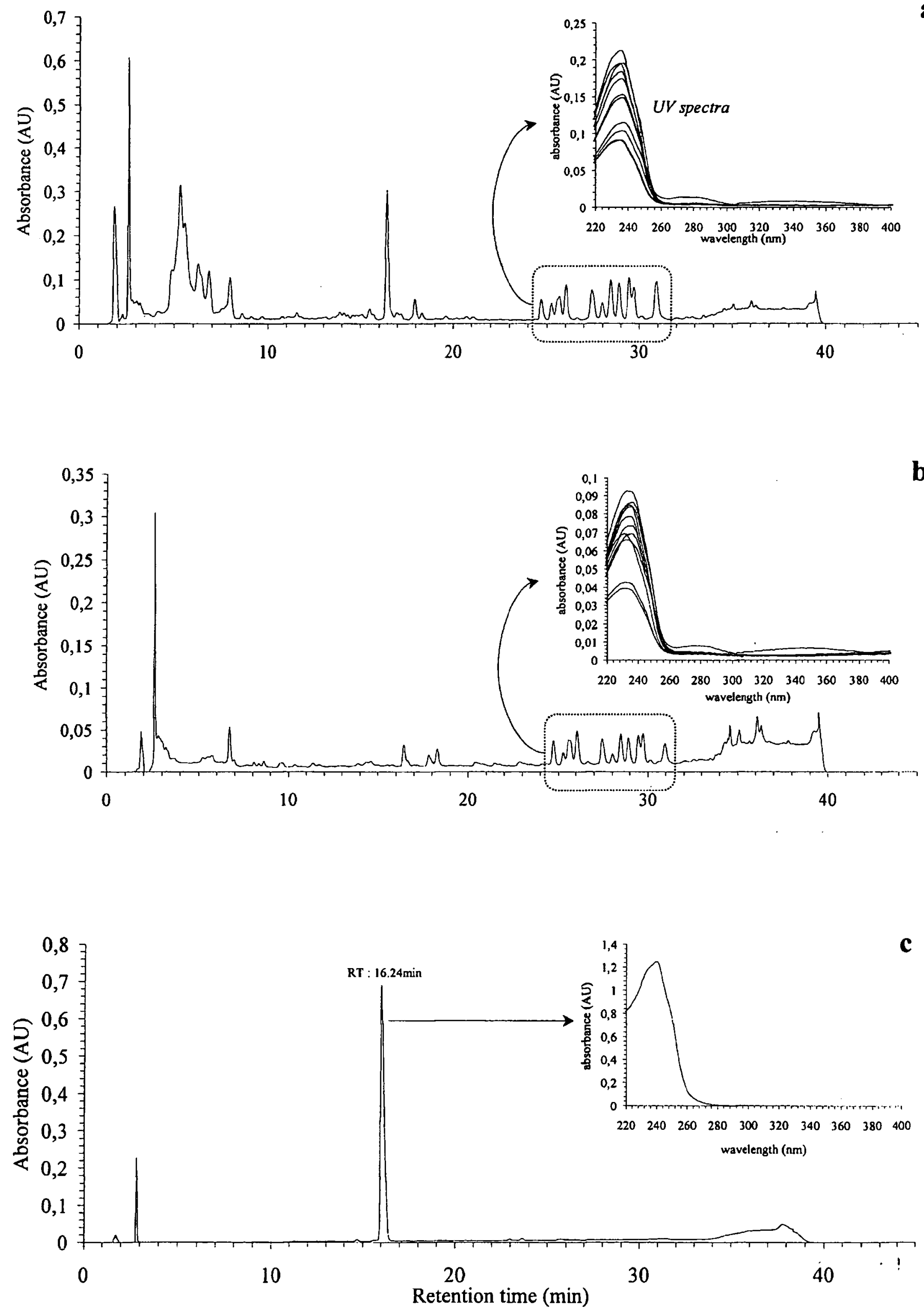

Fig. 6. HPLC chromatograms and UV spectra of Microcystis ichthyoblabe bloom (a), isolated strain (b) and microcystinLR standard (c).

Fig. 6. Chromatogrammes HPLC et spectres UV du bloom à Microcystis ichthyoblabe (a), de la souche isolée (b) et du standard de la microcystine-LR (c). 
species and other potentially toxic species like Anabaena aphanizomenoides and Prymnesium parvum, are in progress.

\section{Acknowledgments}

This work was supported by PARS Project $N^{\circ} 189$ Biology «Programme d'Appui à la Recherche Scientifique au Maroc» and the cooperation project CNCPRST- Morocco / ICCTI- Portugal.

The hepatotoxicity confirmation by anatomopathological liver examination was kindly performed by Dr. Dadi-El-Andaloussi, Laboratory of Pathology Tensift, Marrakech.

\section{References}

AFNOR 1994. - Recueil des normes françaises, eaux, méthodes d'essais. AFNOR Paris.

Carmichael W.W. \& Falconer I.R. 1993. - Diseases related to freshwater blue-green algal toxins and control measures. In Algal toxins in seafood and drinking water. Falconer I.R. (ed.). Academic Press, London. Chapter 12 : 187-209.

Carmichael W.W. 1996. - Toxic Microcystis and the environment. In Toxic Microcystis. CRC Press. Chapter 1:1-11.

Derraz M. 1995. - Etude de l'eutrophisation de la retenue du barrage El Kansera (Maroc). Thèse, Univ. Moulay Ismail, Méknès : $120 \mathrm{p}$.

Falconer I.R. 1998. - Algal toxins and human health. In The handbook of environmental chemistry, Springer Verlag. Vol. 5 Part C : 53-82.

Falconer I.R. 1999. - An overview of problems caused by toxic blue-green algae (Cyanobacteria) in drinking and recreational water. Environ. Toxicol., $14: 5-12$.

Gkelis S., Vardaka E. \& Lanaras T. 2000. - Occurrence of Microcystis in Greek lakes. Abstract. In Proceedings of Eurocyan workshop : Europe facing toxic cyanobacterial blooms. Univ. Paul Sabatier Toulouse, France.

Healey F.P. 1982. - Phosphate. In The biology of Cyanobacteria. Carr N.G. \& Whitton B. A. (eds). Oxford Blackwell Scientific : 105-124.

Huber-Pestalozzi G. 1938. - Das Phytoplankton des Sübwassers. Die Binnengewässer, 16(1) : 1-342.

Hughes E.O., Gorham P.R. \& Zehnder A. 1958. - Toxicity of unialgal culture of Microcystis aeruginosa. Can. J. Microbiol., 4 : 225-236.

Jochimsen E.M., Carmichael W.W., An J., Cardo D.M., Cookson S.T., Holmes C.E.M., Antunes M.B. de C., Filho D.A. de M., Lyra T.M., Barreto V.S.T., Azevedo S.M.F.O \& Jarvis W.R. 1998. Liver failure and death after exposure to microcystins at a haemodialysis center in Brazil. New Eng. J. Med., 338 (13) : 873-878.

Komarek J. \& Anagnostidis K. 1986. - Modern approach to the classification system of cyanophytes ; 2- Chroococcales. Arch. Hydrobiol. Suppl. 73 (Algol. Studies 43) : 157-226.

Komarek J. 1991. - A review of water-bloom forming Microcystis species, with regard to populations from Japan. Arch. Hydrobiol. Suppl. 42 (Algol. Studies 64) : 115-127.

Kopp R. \& Hetesa J. 2000. - Changes of Haematological indices of Juvenile Carp (Cyprinus carpio L.) under the influence of natural populations of cyanobacterial water blooms. Acta Vet. Brno, 69 : 131-137.
Kotai J. 1972. - Instructions for preparation of modified nutrient solution $\mathrm{Z} 8$ for algae. Norwegian institute for water research. Blindem. Oslo. B-11/69: 5 p.

Kuiper-Goodman T., Falconer I.R. \& Fitzgerald J. 1999. - Human health aspects. In Toxic cyanobacteria in water: A guide to their public health consequences, monitoring and management. Chorus I. \& Bartram J. (eds) : 113-153.

Lawton L.A., Edwards C. \& Codd G.A. 1994. - Extraction and high-performance liquid chromatographic method for the determination of microcystins in raw and treated waters. Analyst, 119: $1525-1530$.

Loudiki M., Oudra B., Sabour B., Sbiyyaa B., Vasconcelos V. \& Franca S. - Taxonomy and geographic distribution of potential toxic cyanobacterial strains in Morocco. Ann. Limnol., submitted.

Oudra B. 2001. - Toxicologie des cyanobactéries (Algues bleues vertes) : Cas d'espèces occasionnant des blooms toxiques dans différents milieux aquatiques du Maroc. Thèse. Univ. Cadi Ayyad, Marrakech : $118 \mathrm{p}$.

Oudra B., Loudiki M., Sbiyyaa B., Martins R., Vasconcelos V. \& Namikoshi N. 2001. - Isolation, characterization and quantification of microcystins in Microcystis aeruginosa dominated bloom of Lalla Takerkoust lake-reservoir (Morocco). Toxicon, 39 : 1375-1381

Paerl H. W. \& Tucker C. S. 1995. - Ecology of blue-green algae in aquaculture ponds. $J$. world aquac. Söc, 26": 109-131.

Paerl H.W. 1996. - A comparison of cyanobacerial bloom dynamics in freshwater, estuarine and marine environments. Phycologia, 35 (6) : 25-35

Pettersson K., Herlitz E. \& Istvanovics V. 1993. — The role of Gloetrichia echimulata in the transfer of phosphorus from sediments to water in lake Erken. Hydrobiologia, 253 : 123-129.

Rodier J. 1984. - L'analyse de l'eau, eaux naturelles, eaux residuaires, eau de mer. Dunod : $1365 \mathrm{p}$.

Sabour B., Loudiki M., Oudra B., Oubraim S., Fawzi B., Fadlaoui S., Chlaida M. \& Vasconcelos V. 2000. - Blooms of Prymnesium parvum N. Carter (Chrysophyta, Haptophyceae) associated with fish mortalities in hypereutrophic brackish lake in Morocco. Harmful Algae News, 21: 8-9.

Sbiyyaa B. 1997. - Déterminisme, écophysiologie, toxicité et implications écologiques du bloom toxique à Microcystis aeruginosa Kütz. (Cyanobactérie) dans le lac de barrage Lalla Takerkoust (Maroc). Thèse. Univ. Cadi Ayyad, Marrakech : 219 p.

Skulberg O.M., Codd G.A. \& Carmichael W.W. 1984. - Toxic blue-green algal blooms in Europe : a growing problem. Ambio, $13: 244-247$.

Smith V. H. 1983. - Low nitrogen to phosphorus ratios favor dominance by blue-green algae in lake phytoplankton. Science, 221 : 669-671.

Starmach K. 1966. - Cyanophyta - sinice, Glaucophyta - glaukofity - Flora slodkow. Polski PWN Warszawa, $2: 808 \mathrm{p}$.

Tilden J. 1910. - Minnesota Algae I. The Myxophyceae of North America and adjacent regions. Minneapolis : 328p.

Utermöhl H. 1958. - On the perfecting of quantitative phytoplankton method. Int. Ass. Theor. Appl. Limnol. Commun., 9 : 1-38.

Watanabe M. 1996. - Isolation, cultivation and classification of bloom-forming Microcystis in Japan. In Toxic Microcystis. CRC Press : 13-34.

Wetzel R.G. \& Likens G.E. 1991. — Limnological analysis. 2nd ed. Springer Verlag, New York : $391 \mathrm{p}$.

Zohary T. \& Robarts R.D. 1990. - Hyperscums and the population dynamics of Microcystis aeruginosa. J. Plankton Res., 12 (2), 423-432. 